
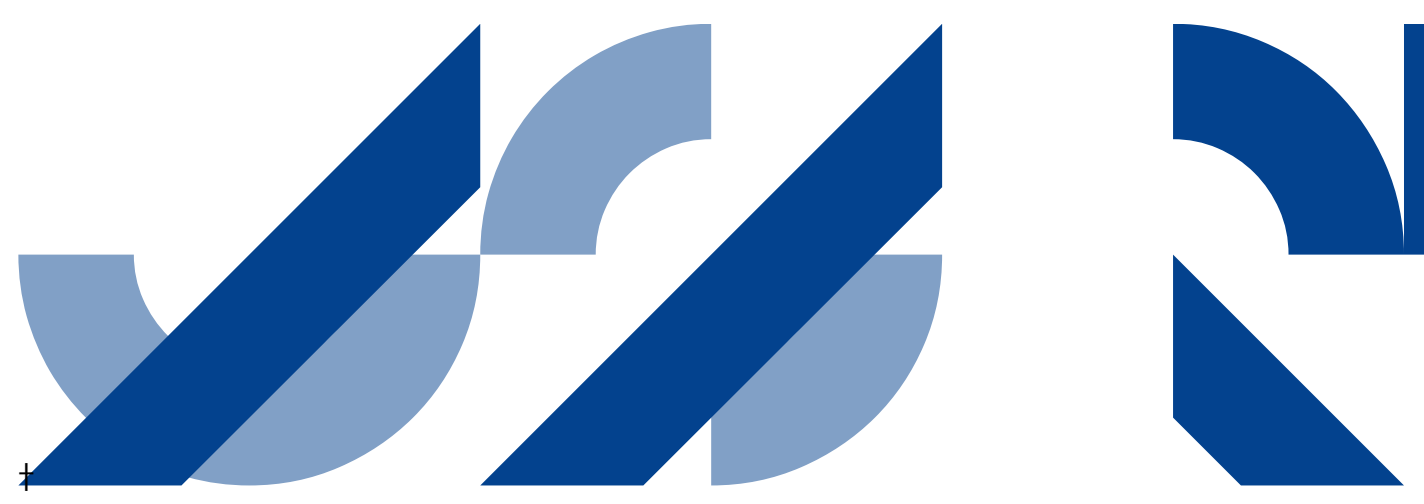

\title{
The geography of peace
}

Egyptian land reclamation and agricultural cooperation with Israel

Hanne Kirstine Adriansen, Associate Professor, PhD 
Title:

The geography of peace:

Egyptian land reclamation and agri-cultural cooperation with Israel

Working Paper

Author:

Hanne Kirstine Adriansen

PhD (geography), Associate Professor

Department of Education

Aarhus University

Tuborgvej 164

2400 Copenhagen NV

Denmark

www.dpu.dk

ISBN: 978-87-7507-355-9

DOI: 10.7146/aul.111.100

(C) 2015 The author 


\section{CONTENT}

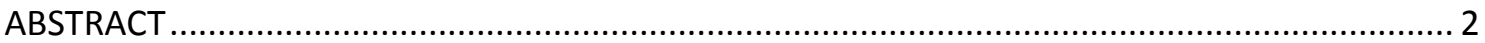

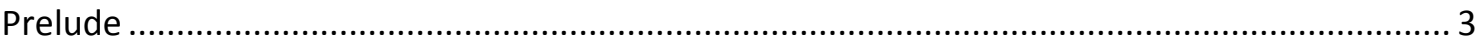

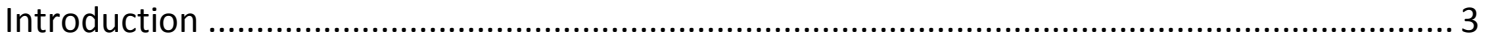

Studying the geography of agricultural cooperation .................................................... 6

A short history of the Egyptian-Israeli cooperation .................................................. 8

Geographies and discourses of land reclamation in Egypt .............................................. 12

The Mubarak Project............................................................................................. 14

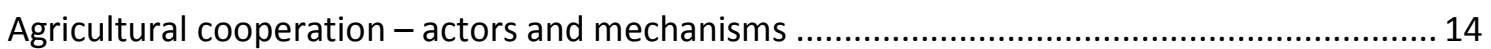

Minister Wali as the facilitator of cooperation ....................................................... 15

"Agriculture is down to earth" - discourses of agrarian development ........................... 16

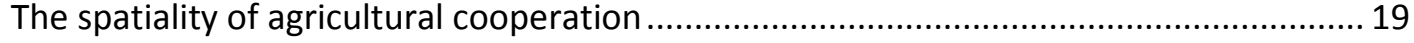

Agricultural training as cooperation - conflicting views .............................................. 20

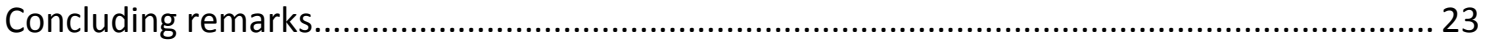

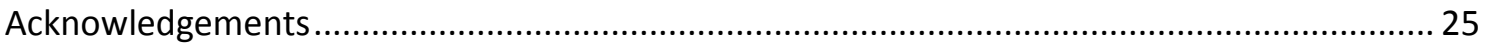

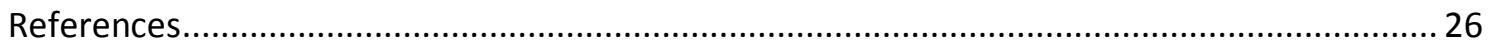




\begin{abstract}
An important aspect of the 1979 Peace Treaty between Egypt and Israel was normalisation through cooperation. However, this has proven difficult; especially the 'Arab street' has been against the collaborative activities. After the Arab Spring, it has been questioned whether the Peace Treaty would be upheld. In order to understand the future of the Egyptian-Israeli peace, this paper uses a geographical approach to examine why agrarian cooperation between the two countries has succeeded when other areas of cooperation struggle. The paper draws on different fields of research - agrarian politics in Egypt, notably land reclamation, and the political economy of The Peace Treaty. These are combined through a geographical gaze focussing on the production of landscape and the construction of space/place. Agricultural cooperation took off when it began to concern desert agriculture. For Egypt, cooperation within this field could be justified through existing discourses of agrarian development by transfer of technology and know-how. For Israel, training courses in particular served as a means to normalisation through image politics. It is concluded that the (spatial) conditions for agricultural cooperation were unique. Thus, despite its continuation, agricultural cooperation in itself holds little hope for the future of the Egyptian-Israeli peace politics of cooperation.
\end{abstract}




\section{Prelude}

At a meta-level, this paper is about the making of research. It shows how research should be understood in the context of those constructing it and the geo-political worlds they inhabit. It is a personal account of how I came across a very interesting topic while researching something else. I pursued this new topic which turned out to be so controversial that I was warned against it by recognised scholars within the field. The first research concerned land reclamation in Egypt and the new topic was Egyptian-Israeli cooperation after the Peace Treaty in 1979. I was warned that I might not be able to resume my fieldwork in Egypt if I chose to dig into the Israeli matter. Yet, this topic was too interesting to leave alone. As a researcher I could not allow myself to be intimidated by potential repercussions of the Egyptian regime. Therefore I began researching the Egyptian-Israeli relations and especially the role of agricultural cooperation in the peace process. The two topics were clearly intertwined. Consequently, I could not continue my research on land reclamation without addressing the Israeli role. However, I could not risk to jeopardise my research opportunities in Egypt and acknowledged the advice given by experienced scholars. I balanced two opposing considerations by doing the research on the peace process, but refrained from publishing it internationally. I limited myself to conference presentations and using it as backdrop for other publications - until now. In the wake of the revolution in Egypt, I felt obliged to share my findings with a wider audience and began writing this paper despite having changed my field of research. However, I find it important that Egyptians gain access to information about the actions of their former regime and its allies.

\section{Introduction}

After the Egyptian president Mubarak's downfall in 2011, the fate of the Egyptian-Israeli peace has been discussed. The sentiment on the 'Arab street' towards Israel is not warm, and a large, although unknown, proportion of the Egyptian population believes that the Peace Treaty should be revoked. Scholars have also raised the issue: "The revolution can legitimately question why the Camp David agreement benefited Israel financially and militarily more than Egypt" (Bush 2011a: 304). While the regime changes so far have not challenged regional peace, there have been changes in the relationship with the US, a relationship that rests on the peace with Israel. Some may argue there is no risk that the Egyptian military will revoke the Peace Treaty with Israel. An analysis from 2011 notes: "The SCAF [The Supreme Council of the Armed Forces] has emphasized that Egypt will adhere to all international treaties and obligations, a reference to its plans to uphold the 1979 peace treaty with Israel". However, the analysis 
continues "The SCAF also has said that it will not field a candidate in a future presidential election" (Sharp 2011: 1). With regard to the latter, SCAF changed its mind when the commander-in-chief and minister of defence, Abdel Fattah el-Sisi, ran for president and won.

The Egyptian-Israeli peace is often labelled 'the cold peace' because the signing of the Peace Treaty in 1979 was not followed by 'normal' neighbourly relations in terms of trade and cooperation (Sharp 2011). Based on multi-sited fieldwork, I provide insights into the spatial dimensions of the cold peace as it was played out in Egyptian agrarian development. In order to understand the future of the peace between Egypt and Israel, this paper draws on two different fields of research - agrarian politics in Egypt, notably land reclamation, and the political economy of the Camp David Accords and the Peace Treaty. These are combined through a geographical gaze focusing on the production of landscape and the construction of space/place.

Cooperation between the Republic of Egypt and the State of Israel began immediately after the Peace Treaty was signed in March 1979. Besides articles concerning Israeli withdrawal from the occupied territories of Sinai, the treaty also included agreements concerning the normalisation of economic and cultural relations. Ever since, normalisation of relations between the two peace partners has been a hot issue in Egypt, even more so after the Arab Spring (Said 2012). Nevertheless, cooperation has taken place, primarily within the agrarian field. As it turns out, agriculture is the only sector in which continuous cooperation has been achieved during the past 35 years. Therefore, agricultural cooperation can be seen as an extreme case in terms of cooperation between the two countries. ${ }^{1}$ In this paper, agrarian cooperation is used as a case to understand the actors and mechanisms that made cooperation work during the cold peace. By exploring if the conditions for this cooperation were unique or if there are some generic elements that can be transferred to other areas, this extreme case can provide understanding of the potential for future Egyptian-Israeli cooperation and continued peace.

As mentioned, the paper draws on two research fields: agrarian development in Egypt and the political economy of the peace. While the dire consequences of Egyptian agrarian policies have been thoroughly analysed by scholars such as Bush (2007, 2011a, 2011b), Dixon (2014)

\footnotetext{
${ }^{1}$ Flyvbjerg (2006: 229) explains the value of extreme cases: "[they] often reveal more information because they activate more actors and more basic mechanisms in the situation studied. In addition, from both an understandingoriented and an action-oriented perspective, it is often more important to clarify the deeper causes behind a given problem and its consequences than to describe the symptoms of the problem and how frequently they occur."
} 
Mitchell $(1991,1995,2002)$ and Sowers (2011), a regional scholarship on agricultural cooperation between Egypt and Israel is non-existent. This may be because agricultural cooperation is seen as tangential to some of the burning questions of agrarian politics in general. The geographical scholarship on agrarian change in Egypt is dominated by research into land reclamation, e.g. Adriansen (2009), Barnes (2012a, 2012b, 2013), Meyer (1978, 1994, 1998). Here too, the Israeli dimension is missing. While Quandt $(1988,2010)$ and other political scientists have provided valuable studies on the peace process, hardly any of the scholarly literature on cooperation and normalisation between Egypt and Israel goes into depth with agriculture as the most successful sector (Keynan and Shoham (1998) is an exception). Moreover, these issues have not attracted a geographical scholarship despite the spatial and geographical dimensions to these issues. This means that existing knowledge about EgyptianIsraeli cooperation is dominated by political and economic analyses (e.g. Kelinberg and Fordham 2010, Reuveny and Kang 1998), while empirically-based, geographical knowledge is missing (Kliot 1997 is an exception). This paper is an attempt to fill this gap. So the aim of this paper is to use a geographical approach to examine why agrarian cooperation has lasted when other areas of cooperation appear to have failed. This focus is inspired by Harvey's call for attention to the ways in which geographical knowledges are produced and used: "Their seeming banality, furthermore, makes it seem as if there is little or no point in interrogating the obvious, when it turns out that this obviousness is a mask for something far more problematic" (2009: 125). Scholars such as Bush (2007) and Mitchell (2002) have argued that focusing on the banality of geography (the demography of the crowded, fertile Nile Valley versus the empty, barren desert) has enabled the Egyptian government to remove attention from the social problems, unequal distribution of land and dire consequences of structural adjustment programmes and neoliberal agrarian politics. Building on the analyses made by Bush and Mitchell, I will show how critical geography focusing on the production of landscape and construction of space/place can be used to understand the development and legitimisation of the cooperation with Israel. Focusing on Egypt in the aftermath of the 1978 Camp David Peace accords, this paper will explore the often neglected ways in which agricultural cooperation became an important asset in the peace politics and especially in the normalisation of relations between Israel and Egypt. In order to do so, the remainder of this paper is structured as follows: In the next section, the analytical approach and the fieldwork are introduced. This is followed by a short history of cooperation between Egypt and Israel. Then geographies and discourses of land reclamation in Egypt are analysed. This leads to the 
analysis of actors and mechanisms in agricultural cooperation. Before concluding, an example of the contrasting views on the outcome of the agricultural cooperation is provided.

\section{Studying the geography of agricultural cooperation}

Geography is inherent within many of the discourses about agricultural cooperation and land reclamation. However, as we will see, the type of geography seen in these discourses may be characterised as 'banal'. They use geography as a means to even out differences, for instance by making all deserts alike, thereby turning the transfer of dryland technology into something that is 'natural'. One of the strengths of the geographical gaze, however, is the focus on particularities (Harvey 2009). Inspired by Smith (1984), Castree (1995) and Harvey (2009), I will analyse the production landscape within the agricultural cooperation. Smith's focus on nature as something which is produced, not given, shows how capitalism makes nature into a tool of accumulation; while Castree (among other things) supplements these thoughts with a focus on the materiality of nature (1995: 20). These ideas are used to study how the Egyptian landscape is produced, how this production focuses on material similarities ('a desert is a desert'), and how various actors thereby turn landscape into a site of collaboration through a discourse of techno-politics. Finally, I will draw on Tuan's (1977) and Cresswell's (2004) notions of space and place to explore the symbolic importance of different landscapes. According to Tuan, space and place require each other for definition and "space is more abstract than place" (Tuan 1977: 6), which means that while space is general, place is particular. In an Egyptian context, a crude generalisation would see the desert as space and arable land where people live as place. Thus, land reclamation can be seen as the 'shaping of space into place'. When analysing the world as a world of places, attachments and connections between people and places can be seen (Cresswell 2004); this is used to explore the spatiality of the agricultural cooperation.

The empirical material for this paper was obtained through multi-sited, ethnographic fieldwork. One part stems from a major research project into Egyptian land reclamation in a human geography perspective (see Adriansen 2003, 2007, 2009; Adriansen and Madsen 2004). This paper is primarily based on interviews with farmers and agricultural engineers in the Western Desert and Cairo between 2002 and 2006, using the timeline interview method (Adriansen 2012). 


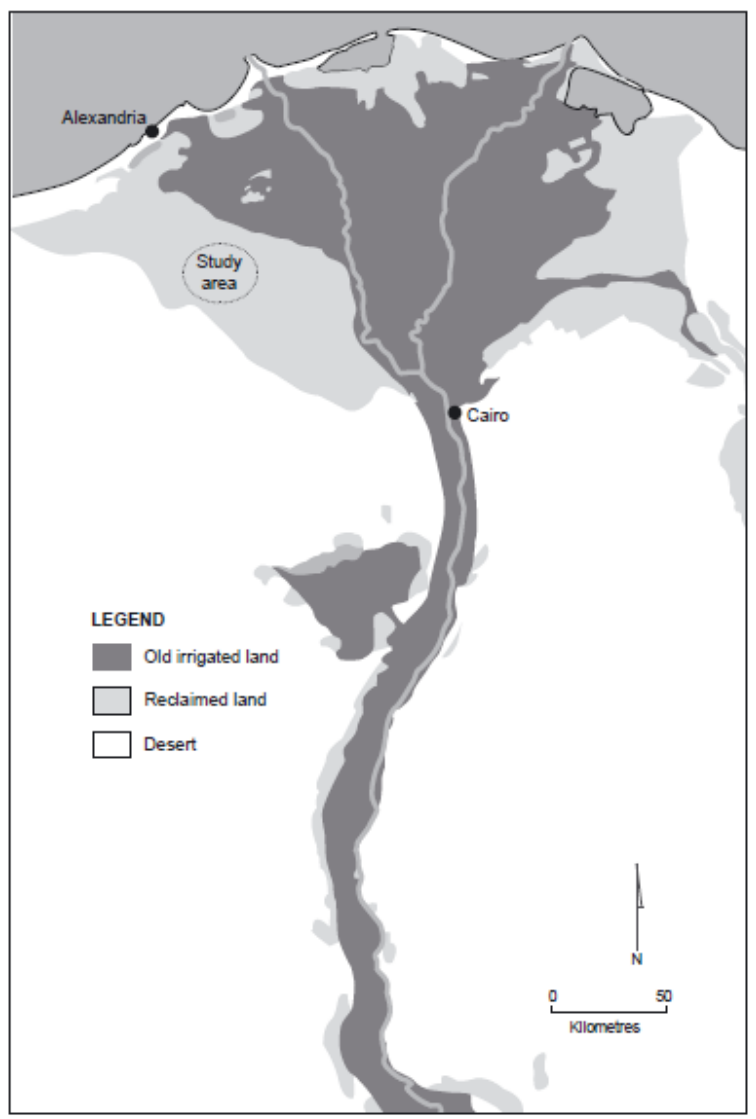

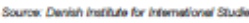

Figure 1. Map of the study area

During this major research project, I realised that land reclamation was integrally tied into Israeli-Egyptian cooperation efforts, which underlined the importance of enlarging the scope of the original research on Egyptian land reclamation. Hence, another part of the empirical material stems from research into the Egyptian-Israeli cooperation. This is based on qualitative interviews and document analysis. I interviewed more than 20 people in Egypt, Israel, Palestine and Denmark, representing a number of different governments, international agencies and NGOs who had all been involved in the collaborative activities in various ways. Some interviewees were key figures who had taken part from the very beginning in 1979, while others were active at the time of the interviews in 2002-2006. As some of them did not want their identity revealed and had been promised anonymity, only nationality and profession are indicated. While the Israelis were very keen on being interviewed, the Egyptians were quite reluctant to talk about cooperation with Israel. It turned out, however, that they perceived it as legitimate when I (as a Dane) asked questions about projects financed by Denmark. Therefore, I focused on projects which had received Danish funding. It should be 
noted that these projects are very similar to other internationally funded 'peace projects'. The most interesting interviews with Egyptians were conducted without a tape recorder or when it was turned off; therefore the majority of the direct quotes are by Israelis. All interviews were conducted in English; I have chosen verbatim quotes rather than linguistically correct ones throughout the paper.

\section{A short history of the Egyptian-Israeli cooperation}

After the Camp David Accords in 1978 and the signing of the Peace Treaty six months later, cooperation between Israel and Egypt became a possibility (Quandt 1988). During the following years of peace, efforts have been made to establish mutual relations within various fields. But these have often failed, apart from the agricultural cooperation (Keynan and Shoham 1998). As it turns out, the desert in particular has been a space for cooperation.

As stated in the Camp David accords, the Egyptian-Israeli peace should be the first step towards resolving the Arab-Israeli conflict, in particular the Palestinian struggle for independence. However, the Peace Treaty did not provide any solutions to the Palestinians. Since 1979, the official Egyptian discourse has been a balancing act between the Peace Treaty emphasising normal relations on the one hand, and the Camp David Accords calling for a solution to the Palestinian struggle for independence on the other (Quandt 1988). And this balancing act has been paralleled by pressure from the international community, especially from donors, to cooperate with Israel versus domestic pressure in Egypt not to normalise relations. It appears that the Egyptian government has tried to satisfy both sides at the same time, often by speaking with two tongues.

Hence, from the very beginning, Egypt and Israel had conflicting reasons for engaging in cooperative activities, and consequently the two countries did not agree on the volume and extent of relations, or on the speed at which ties should be built. While Israel wanted to increase economic relations and cooperation, Egypt preferred to keep relations at a minimum (Shehata in MEI 2009). From the Israeli point of view, economic relations, such as trade, investments and movement of people, goods and services, provided the concrete contents of peace. For the State of Israel, cooperative and economic relations are also a 'proof' of normal relations between two countries at peace. Without these flows, the Israelis argued, peace would remain empty and fragile and could easily be broken (Arad et al. 1983). Egypt, on the other hand, maintained that by accepting the Peace Treaty, the Republic of Egypt had granted 
Israel formal recognition for the first time since the foundation of the State of Israel. Hereby Israel was ensured peace with one of its greatest adversaries, by the country that had played a leading role in the Arab-Israeli wars (Walker in MEI 2009). Moreover, the costs of peace for Egypt were high in terms of the loss of importance, respect and economic relations with the rest of the Arab world. Shortly after the treaty had been signed, the Arab League passed a series of resolutions to disrupt diplomatic relations with Egypt and impose economic sanctions on the country (Quandt 1988). The economic loss, however, was to some extent covered by the US. After the Peace Treaty was signed, Egypt became the second-largest recipient of US assistance in the world after Israel. The US has been a major sponsor of the Egyptian dictatorship, giving it extensive leverage with the Mubarak regime (Sharp 2013). However, for Egypt peace was costly and the president Anwar El Sadat paid the ultimate price when he was killed by resentful Islamists during a military parade in 1981 (Gerges 1995). In sum, both countries found that they had not reaped the fruits of peace despite some relations and cooperation.

Agriculture was the first area where connections were established. Only seven months after the Peace Treaty was signed, an Israeli agricultural delegation arrived in Egypt. This was a meeting of historical significance as it created the foundation for a Joint Egypt-Israeli Agricultural Committee, and practical cooperation has been on-going ever since. During the meetings, Youssef Wali (former minister of agriculture and deputy prime minister) was appointed Egyptian coordinator, while Samuel Pohoryles (former director of the Peres Center for Peace) was nominated Israeli coordinator (interview, Israeli $A^{2}$ ). In spring 1980, when full diplomatic relations between the two states were established, the Joint Agricultural Committee (JAC) was established with a view to facilitating cooperation between the two states in agricultural and rural development projects, with Wali and Pohoryles as co-chairmen (JAC 1999). These people played a leading role in maintaining the cooperative climate between Egypt and Israel. From the very beginning, the cooperation had the dual purpose of developing agriculture and promoting peace. Since then, agriculture has been labelled the major "peacepromoting activity" and the cooperation seen as "a prototype of cooperation between former enemies" (JAC 1999: 4). In addition to JAC, the USAID-sponsored Middle East Regional Cooperation (MERC) programme (established in 1981) was also important because it served as a framework for the transfer of agricultural knowledge and technology. MERC also provided

\footnotetext{
${ }^{2}$ NGO director, interviewed $17 / 3 / 2003$.
} 
the framework for the normalisation of relations between Israel and Egypt and, later, with other Arab countries (Keynan and Shoham 1998).

The 1979 treaty specified that Israel would purchase oil from Egypt, and in May 1980 the two countries signed an agreement on trade and commerce as a step towards normalising relations (Arad et al. 1983). Trade relations mainly developed in areas such as textiles and cotton, machinery, chemicals and vegetables; so there was a strong bias towards the agricultural realm. The two countries both have textile sectors, albeit with quite different profiles, making it possible to exploit complementarities (Arad et al. 1983). Generally, initiatives aiming at cooperation have come from Israel for the reasons outlined above. USAID and other development agencies have also been instrumental in facilitating and not least financing cooperation between the two countries. These suggestions for bilateral cooperation have been given a mixed welcome in Egypt (interview Egyptian $A^{3}$ ). In 1998, for instance, Israeli requests to buy natural gas and to partly finance the renovation of the library in Alexandria were declined. And in April 2000 - before the second Palestinian intifada - the Egyptian minister of electricity, Ali El-Saedi, made Egyptian-Israeli talks on power cooperation dependent upon progress in peace talks. However, the natural gas deal was completed in autumn 2003 despite the deterioration in the Palestinian situation. Through the 2000s came development of infrastructural projects such as the gas pipe to Israel (which was sabotaged several times after the Egyptian uprisings) and US-sponsored Qualified Industrial Zones (QIZs) - free-trade zones including Israel and one of its Arab peace partners (Azmeh 2014). While Israel has benefitted from unique free-trade agreements with both the US and the EU for decades, this was not the case for Egypt (Yetiv 1997). However, the economic benefit of easy access to overseas markets was not enough to convince the Egyptian population in 1999; due to resistance a QIZ agreement was achieved with Jordan only (Ezzat 1999). However, a QIZ agreement between Egypt, Israel and the US came into force in 2005. It meant that goods made in Egypt with at least $10.5 \%$ Israeli content can enter the US duty-free. The agreement made it possible for Egypt to expand its exports and create jobs exploiting the cheap Egyptian labour, as seen in Mahalla, and commodities produced in the QIZs now constitute one-third of Egypt's US exports (Sharp 2011). ${ }^{4}$

\footnotetext{
${ }^{3}$ Scholar, interviewed 25/10/2003.

${ }^{4}$ It should be noted that Mahalla has become known as a site of strong protests. A three-day strike of textile workers has been labelled a major turning point in the history of the Egyptian workers' movement (El-Mahdi 2011).
} 
The intensity of relations has oscillated in accordance with Israeli-Palestinian relations (interview Egyptian A). For instance, the Oslo Accords in 1993 gave rise to new agreements and lukewarm relations, but these turned cold after the outbreak of the second Palestinian intifada in September 2000. This intifada even caused Egypt to recall its ambassador from Israel, and in March 2002 the situation deteriorated when Israel reoccupied large parts of the Palestinian territory. This caused the Egyptian government to suspend all inter-governmental ties with Israel except diplomatic channels dealing with the Palestinian issue (Abdelaty 2003).

While the 'peace dividend hypothesis' has been perceived as the principal driver of US economic aid to Egypt (Ebeid in MEI 2009), peace dividend has a number of different meanings in the literature and public debate. As noted by Ebeid: "Since the peace accords in 1979, Egypt has become the most important US ally in the Arab world. Since that time, Egypt has been the second largest recipient of American economic and military assistance - Israel being the first. From the late 1970 s until the late 80 s, Egypt and Israel received almost $50 \%$ of total US economic assistance" (Ebeid in MEl 2009: 27). This is the idea of an economic dividend where the US pay Egypt and to a lesser extent Israel (which already received substantial economic aid from the US) to maintain long-term peace (Zimmerman 1993). In the Egyptian public, however, US aid politics are often seen as serving US political interest first and foremost. The way aid has been given has increased food dependency and had other negative impacts on Egyptian development (Mitchell 1991). Egyptian cooperation with Israel has never been popular on the 'Egyptian street', where peace divided would entail a sustainable solution to the Palestinian suffering; hence this could be labelled a Palestinian-solution dividend. In Israel, the peace dividend is perceived as normal relations in terms of trade, culture and types of cooperation, which in turn are thought to have positive economic effects (Yetiv 1997). Hence, there are a number of different perceptions of what the peace dividend should entail and through whom it should be provided. MEI (2009) offers a collection of different analyses and viewpoints on the legacy of the peace process and the different rationales regarding peace dividends. For peace brokers, peace in and of itself was the ultimate goal behind their decisions; whereas for other actors large economic and political gains were at stake. This logic of regional peace and security through economic dividends has marked the cooperation - both the bilateral cooperation between Egypt and Israel and the multilateral cooperation promoted by USAID and other international donors. 
Thus cooperation has been difficult and the agricultural sector stands out for the long and sustained relations that were established from the very beginning. The majority of Israeli cooperation efforts were concentrated on desert development on the western fringes of the Nile Delta, in the 'Mubarak Project' and a handful of other reclamation areas. Therefore the remainder of this paper will examine why agricultural cooperation has lasted and why desert land reclamation became the focus of this cooperation. First, a brief introduction to land reclamation in Egypt is necessary.

\section{Geographies and discourses of land reclamation in Egypt}

Land reclamation has been on the political agenda in Egypt for more than 60 years. After the 1952 revolution, increased agricultural production through reclamation of desert lands was declared to be among the most important objectives of the new government (Meyer 1978; Wolff 1993). Since then, land reclamation has been used discursively as a remedy for all sorts of problems from desertification to terrorism (Adriansen 2009), and the various land reclamation projects should be understood in the context of the neoliberal agrarian politics in Egypt (see e.g. Barnes 2013, Sowers 2011). The principal purpose of land reclamation is to increase the agricultural production and "overcome Egypt's overwhelmingly unfavourable population to land ratio" (Springborg 1979: 54). This is both the official discourse of the Ministry of Agriculture and Land Reclamation (MALR), and the line of reasoning found in much literature (e.g. Ibrahim and Ibrahim 2003). It is argued that with a growing population there is a pressure to increase the agricultural production, and that it is not enough to bring more intensive means of cultivation into practice - spatial (horizontal) expansion is necessary. Apart from the delta and the Fayoum oasis, only a narrow strip along the Nile is cultivated and the population is also concentrated in these areas. A mere 4\% of Egypt's total area is cultivated, and this area has one of the highest population densities in the world (Wolff 1993). Through this discourse, landscape is produced in simple binaries as cultivated/uncultivated or crowded/empty, and the reclamation of the desert is presented as natural, almost inevitable in light of the population growth and increased congestion in the so-called old lands, the Nile Valley and the delta. However, without a view on the particularities of the landscape, we overlook how the quality of the soil in some of these areas has deteriorated and people have become impoverished (Malm and Esmailian 2012). 
There are a number of important discourses which stakeholders involved in the cooperation between Israel and Egypt draw upon. In his analyses of 'America's Egypt', Mitchell $(1991,1995)$ shows the discourses of the development industry and how they pertain to the agrarian development. Before addressing the implication of these discourses for the agricultural cooperation, the discourse of land reclamation is worth mentioning. As pointed out by Barnes, reclamation is "a slightly misleading term since it is not a process of re-claiming something that has been lost but of creating something new" (2012b: 535). The majority of 'reclaimed' land in Egypt is desert and has been so for millennia. Hence it is not entirely correct to label this reclaiming. Desert land reclamation in the Egyptian context means converting desert areas into arable land and rural settlements. ${ }^{5}$ This is done primarily by extending water canals from existing agricultural areas along the Nile into the desert, but also by working with the soil, ploughing in manure in order to enhance its fertility, and finally by providing the infrastructure for making new villages. Egyptian farmers have long reclaimed desert land and dealt with salinity in the border areas between the desert and the Nile Valley, so the notion of a rigid divide between irrigated land and desert is problematic. Even so, Egypt's agricultural areas are often referred to as the old lands, the old new lands, and the new new lands (interview Egyptian $\mathrm{B}^{6}$ ). The old lands refer to the fertile arable areas in the Nile Valley, the delta and the Fayoum oasis. The old new lands are desert areas reclaimed many years ago, which have come into continuous cultivation and lost their desert appearance. These are usually more than $\mathbf{4 0}$ years old and located along the old lands and can be difficult to distinguish from these. Finally, the new new lands are those most recently reclaimed. It remains difficult to estimate how much desert has been converted into agricultural land, both because spontaneous, illicit reclamation takes place and because reclaimed areas are taken out of cultivation due to the insufficient quality and quantity of the irrigation water, salinisation and other types of degradation (Barnes 2012a, Sowers 2011). Nevertheless, it is estimated that over the past 50 years more than $12,000 \mathrm{~km}^{2}$ of desert land has come under cultivation, which means that Egypt's agricultural area has increased 20-25\% due to land reclamation (Barnes 2012b). It is important to notice, however, that in terms of agricultural production, the new lands contribute less due to lower soil fertility and problems with the irrigation infrastructure. The biophysical ecology and dire environmental consequences of land reclamation have been

\footnotetext{
${ }^{5}$ Please refer to Nielsen and Adriansen (2005) for a spatial analysis of the conversion of desert to arable areas.

${ }^{6}$ Agricultural engineer, interviewed 19/11/2002.
} 
analysed by Enien et al. (2000), Dixon (2014) Kamel and Dahl (2005), and Malm and Esmailian (2012) and will therefore not be further discussed here.

\section{The Mubarak Project}

There have been a number of different state-sponsored and private land reclamation schemes. Meyer $(1994,1998)$ and Sowers (2011) have analysed how different land reclamation schemes have catered for different social groups. One of these schemes is 'The Mubarak Project', which was initiated in 1987 and had a high profile in the MALR for more than 20 years. This project was central to some of the cooperation efforts between Egypt and Israel; therefore I will use this for further analysis. The Mubarak Project, which granted land to young graduates, relied on development aid from a number of countries and organisations, e.g. the World Food Programme, USAID and Danida (the Danish International Development Agency). The majority of reclaimed land for the Mubarak Project was located on the western side of the delta and received water through irrigation canals pumping water up from the Nile (interview Egyptian $C^{7}$ ). The MALR states that the underlying rationale is that young graduates can be trained in cultivating land, and at the same time the Mubarak Project can help diminish graduate unemployment (MALR 2000). In the words of Malm and Esmailian, the Mubarak Project "pulled together several distinctive threads running through the Mubarak era: unemployment, dispossession of farmers, agribusiness expansion, and dependency on international institutions" (2012: 480). What Malm and Esmailian forgot was another important tenet of the Mubarak regime: cooperation with Israel.

\section{Agricultural cooperation - actors and mechanisms}

Why has agricultural cooperation been established and lasted when other areas of cooperation and relations appear to have failed? Interestingly, the Egyptians and Israelis (involved at different points of time) gave similar answers to this question:

Israeli $\mathrm{B}^{8}$ : "I have two reasons for it. First is the personality of the minister of agriculture, the other is that agriculture is the backbone for other sectorial development in Egypt."

\footnotetext{
${ }^{7}$ Under secretary, interviewed 20/11/2002.

${ }^{8}$ Deputy of one of the first projects, interviewed $17 / 8 / 2003$.
} 
Egyptian A: "Why agriculture? Egyptians is interested in this agriculture and the Israelis got some experience on that direction. So there was a co-operation. But also I must say that usually you need sympathetic personnel on that one. And a personality of Wali in particular."

Israeli $C^{9}$ : "You have to find those very, very narrow sectors in which there is interest also on the Egyptian side, and right now the only one is training and development and agriculture. That's what they want from Israel, that's what Israel is willing to give [...] other things are much more problematic. Agriculture is down to earth."

We will take a closer look at these two explanations in the following analysis of the interviews.

\section{Minister Wali as the facilitator of cooperation}

There is no doubt that the personality of the minister of agriculture, Wali, has played an important role in the agricultural cooperation, which he was engaged in from the very beginning albeit not as a minister but as a university professor. The evaluation of Wali was similar among Israelis and Egyptians:

Israeli $\mathrm{D}^{10}$ : "We always wanted to spread out not only from agriculture but to related subjects. Politically, the only ministry in Egypt that cooperated with us was the ministry of agriculture, no other ministry [...] The minister was one with an open mind [...] The Danish colleagues, when they negotiated the agreement for the regional programme understood very well that they should negotiate only with the ministry of agriculture and not with the foreign ministry."

Egyptian A: "[Wali cares] about political considerations, he wants his sector to succeed".

Israeli B: "Wali was very supportive, breaking the ice through international or through technical cooperation. And at the beginning the number of Egyptians coming to Israel was very, very limited by policy of Egypt, until much later, and I've forgotten the exact year, Wali in one of these joint meetings certainly said he would like to see hundreds of Egyptians coming to Israel for training and that changed the whole picture [...] And I must give credit to Fouad and Wali personally, and they did have that vision, a good vision that this is the only way we could build a peace, a true peace."

There is no doubt that Wali and his close employee Fouad Abu Hadab have been important in facilitating the agricultural cooperation during its first 20-25 years. However, his popularity in

\footnotetext{
${ }^{9}$ NGO consultant, interviewed $17 / 8 / 2003$.

${ }^{10}$ High-ranking government official, interviewed 12/8/2003.
} 
Israel and in the international aid community was matched by strong resentment in the Egyptian population, who accused him of normalising relations. Even back in the mid-1990s Wali came under severe criticism from the Egyptian opposition for his involvement in IsraeliEgyptian cooperation, with people claiming that cooperation was undermining Egypt's society, agriculture and natural resources, as well as weakening Egyptian identity and enabling Israeli infiltration and domination. The newspaper Al-Shaab, for instance, accused Wali of "high treason" (El-Din 2000). ${ }^{11}$ There were a number of trials against Wali, and in 2004 he had to step down. Nevertheless, the cooperation continued. Hence, Wali's attitude towards Israel cannot explain the continued success of agricultural cooperation. Therefore we may need to look closer at the agricultural sector and the discourses employed by the interviewees.

\section{"Agriculture is down to earth" - discourses of agrarian development}

As Mitchell has shown $(1991,1995,2002)$, post-peace development politics in Egypt was shaped by its new ally, the US. In particular, agrarian development has been closely linked to the US - and to the needs of the agricultural sector in the US: "The largest site in the world to be incorporated into this system of state-subsidized American farming has been Egypt" (Mitchell 1991: 31). When the Mubarak regime began to implement reforms to the agrarian sector along neoliberal lines from the end of the 1970s, the minister of agriculture, Wali, was working "hand in hand with USAID and the World Bank" (Bush 2011b: 396). This transformation (through land reclamation and other mechanisms) of Egyptian agricultural policy and practice was linked not only to major processes of 'modernisation', technology transfer/mechanisation, economic liberalisation, state/national ideology etc., but also to the normalisation of relations with Israel. In his analysis of the development discourse in Egypt, Mitchell argues that Egypt "wishes to present itself as a detached center of rationality and intelligence. The relationship between West and non-West will be constructed in these terms. The West possesses the expertise, technology and management skills that the non-West is lacking" (1991: 33). By focusing cooperation within a field - and a landscape - where Israel could be said to possess expertise and technology, such cooperation might be justified. Therefore, it became important to find the right area for cooperation - in terms of both physical geography and location. When the agricultural cooperation with Israel began, the Nile Delta was the first site of cooperation. At a demonstration site, Israeli experts introduced drip irrigation. According to Israeli B, it was the first time drip irrigation was used in Egypt and the

\footnotetext{
${ }^{11}$ This can be followed in the English-language weekly Al-Ahram Weekly.
} 
Egyptian professionals involved were very suspicious. The Israelis claimed that drip irrigation and sprinklers provide the best means of irrigation, but as Barnes has shown, the transfer of technology is not that simple: "Not only are sprinklers expensive to install, operate and maintain, but few of the smallholder settlers would be familiar with their use. In addition, the trials showed that contrary to expectations, the efficiency of water use was lower with sprinkler irrigation. On fields where they used sprinklers, consultants found a soil crust developed which caused up to 40 percent of the water applied to runoff over the surface" (Barnes 2013: 258-9). The Egyptian suspicion made cooperation difficult; and in addition some of the Israelis directly involved in the cooperation found that they had little to offer Egyptians as far as cultivation in the old lands was concerned (interview Israeli $\mathrm{E}^{12}$ ). In terms of desert agriculture, however, Israel had the technology and know-how Egypt needed, as Israeli B said during an interview:

"Because the feeling was that our experience with the shortage of water was, would be more relevant to the Western Desert than to the delta where there is plenty of water. [...] And there [Nubareia State Farm] we decided with his [Fouad Abu Hadab] enthusiasm to introduce some new technologies."

Therefore, the land reclamation schemes in the Western Desert soon became the focal point. From this point on, the cooperation took off. Desert cooperation could make cooperation with Israel legitimate from an Egyptian point of view - within the discourse of agrarian development and techno-politics outlined by Mitchell $(1991,2002)$. When I asked interviewee $E$, who had been directly involved in some of the first projects, if the agricultural cooperation would have been the same if it had remained in the delta, he replied: "Of course not [...] we have more knowledge about desert or sand... soil than the Egyptians had before. They didn't believe that we can grow something in the desert." He seemed to forget that land reclamation and cultivation of the Egyptian desert had been taking place for decades before the Israeli involvement. However, some of the major public schemes were developed after the peace treaty, with cooperation with Israel being used to develop the village infrastructure and the farming technologies:

Israeli B: "I think that Egypt understood that there's plenty of technology that was developed over 50 years [in Israel] that can be adapted to Egypt. [...] I think that our function in the

\footnotetext{
${ }^{12}$ Lower-ranking government official, interviewed 17/8/2003.
} 
settlement of graduates [the Mubarak Project] was a very important one. We were able to show the Egyptians that you can make a living on a very small physical area of land."

The production of landscape disclosed in this statement is a landscape of similarities in terms of physical geography. But in terms of knowledge there is some difference, since Israel is portrayed as possessing superior (Western) technology. ${ }^{13}$ The quote shows the interviewees' limited knowledge of Egyptian agriculture. The old lands are extremely fertile, so delta farming requires much smaller plots than desert farming. For Egyptians, desert farm sizes sound very large, which has also led some of the new settlers to believe that they could make a profitable living because they did not take the low fertility of sandy, desert soils into account.

Israeli C: "Now the farmers of the delta are very good farmers, but they have their own traditional methods. They don't know how to cultivate the desert and when then do go into cultivation and irrigation, they do it by flooding, you know, open these canals, push the water in and flood it. That's the way they know, and that's what most farmers do in less developed agricultural sectors."

In this quote, the differences within the Egyptian physical geography are acknowledged; but it is maintained that the power of knowledge belongs to Israel, while Egyptian farmers are "less developed". In order to teach Egyptian farmers modern technologies, training courses were designed. Israel found that engaging in these courses might serve one of Israel's needs in terms of peace politics. As argued above, normalisation has been the main purpose for Israel; but owing to the negative perception of the State of Israel in the Egyptian public, this normalisation has been difficult to achieve. Consequently, Israel has tried turning (agricultural) cooperation into image politics ${ }^{14}$. One way of doing this was by having Egyptians come to Israel and see for themselves that - as phrased by Israeli D "we are not growing horns". Making training courses in desert agriculture for young Egyptian farmers seemed to be an obvious solution: "Since 1989, the training program has become one of the most important, if not the most important component of Israeli-Egyptian cooperation in agriculture" (Keynan and Shoham 1998: 1991). Over the years, more than 5,000 Egyptian farmers have attended training courses in Israel. The majority of these have been graduates who have been granted

\footnotetext{
${ }^{13}$ The notion of Israel as holding superior environmental knowledge has also been described by Cohen (2011) in his comparison of the environmental imaginaries of Palestinians and Israelis in the context of nationalism(s) and environmentalism.

${ }^{14}$ As noted by van Ham (2001: 3), countries are increasingly becoming 'brand states' through postmodern politics of image and reputation: "Image and reputation are thus becoming essential parts of the state's strategic equity".
} 
land under the 'Mubarak Project'. An increase in training activity was achieved by the so-called Trilateral Training Programme (TTP) signed by the governments of Denmark, Israel and Egypt in 1993 (IMFA 1998). During this warm period of the peace (after the signing of the Oslo Accords), Israeli experts also lived in the Egyptian desert and offered training courses and technological expertise:

Israeli D: "We were very fitting for this training. [...] Because this form of settlement in the desert was not new to us, we did it here, in northern Negev. The terrain is similar, I think rainfall may also be similar, or maybe we get a little more. The types of crops are similar."

This quote is another example of landscape being produced as similar whereby the discourse about Israeli knowledge superiority and dominance is reproduced.

Summing up, agricultural cooperation took off when it began to focus on desert development. For the Egyptians, cooperation within this field could be justified through the discourses of agrarian development, and through the transfer of technology and know-how. For the Israelis, training courses in particular served as a means to achieve normalisation through image politics.

\section{The spatiality of agricultural cooperation}

Apart from these explanations, expressed by interviewees in Israel and Egypt, there is another interpretation which encompasses 'environmental imaginaries' (Davis and Burke 2011) and spatial differences within Egypt: the difference between the Nile Valley and the desert. This difference in landscape and physical geography is also reflected in Egyptians' mental geography (interview Egyptian A). The Nile has a strong symbolic connotation in the desert country, where it is seen as a blue line meandering through the desert providing the inhabitants with a livelihood. Egyptians have cultivated the fertile soils of the Nile Valley for millennia. They have a profound knowledge of the rhythm of the river and the character of the land, which they learned to master long ago. With the construction of the Aswan Dam, the pulses of the river changed, but the farmers still knew how to make the land yield a good harvest. Hence, the Nile Valley can be regarded as a place with strong importance for the construction of the Egyptian identity. The desert, on the other hand, is often considered an empty space, and the Bedouins living there are marginalised (Lavie and Young 1984). While land reclamation has transformed a small part of this empty space into an inhabitable place, it is not part and parcel of the Egyptian identity. Despite the increasing territorial integration, the 
desert is the periphery (Drozdz 2011). While it might be dangerous to let the 'enemy' over the frontier, it is better to have him on the periphery than at the heart of the country. The desert communities are less crowded and controlled. Therefore they became sites of collaboration. This interpretation of space and place is reflected in the comments of one of the Egyptian interviewees, who also pondered the difference between the inhabitants of the delta and the desert:

Egyptian A: "Generally the people going to this new land are very young and as such they are better educated and as well as I would say open-minded to some extent. These are all factors into why it [agricultural cooperation] is happening there but not in the delta or inside the valley."

This spatial construction of the desert as the periphery where different rules apply is recognised to some extent by the settlers of the area, as the following example illustrates.

\section{Agricultural training as cooperation - conflicting views}

The training of graduate farmers from the Mubarak Project can be used as an example of the conflicting views on the outcome of cooperation policies. By employing the discourse of desert development through the transfer of technology and know-how, the cooperative training projects were described as a success in project documents and by some interviewees, e.g. Israeli E:

"Many people who come here they weren't very sure that this was the right thing they were doing. But when they first find that we are here and we have a successful agriculture and they could learn, they start be quiet and believe more and more. I am sure that if the intifada wasn't now we could have a lot of training courses with Egypt."

While the Israelis were aware of the sensitive political situation, an Egyptian scholar diminished it:

Egyptian A: “Egyptians don't give a damn about Israelis or Americans or whatever. Egyptians are usually a very hardworking people under very harsh circumstances and they want to make their living, and raise their kids to the best they can. [...] These people who decide to go to the desert. Actually, they are breaking with a lot of things [...] they need all the help they can get and they don't put a label on the help." 
However, these statements did not reflect the sentiments I met during fieldwork in the Mubarak villages. Even though some of the interviewees had been to Israel on training courses paid by Danida, they were not too proud of it. One graduate farmer, Egyptian $D^{15}$, had participated three times in 1996-97, but "at first nobody wanted to go because it was Israel". Here is his account:

Egyptian D: "We had three objectives - to learn, to travel, and to relax. Their [the Israeli] objectives were: To show how superior they were in technology and it was much exaggerated, they wanted to show they were superior. They have great agriculture, but it was exaggerated. Their second objective was to market their products; they would exaggerate their yields and get us to buy the fertilizer, their seed. Their third [objective] to get money. Danes paid $\$ 2500$ for each trainee, staying at the kibbutz and it did not cost the Israelis $\$ 2500$ to have us stay there."

Here the farmer reproduces the discourse of Israeli technological superiority and the need for desert settlers like himself to learn. Thus, the discourse on development and techno-politics (Mitchell 1991, 2002) can be traced from high-level bureaucrats and development workers all the way to the farmers. The interview continued:

Me: "What did you learn?"

Egyptian D: “I didn't learn anything new. All the farms had salty soil, they were along the Dead Sea, so it was very different from what we have here. They had water melons and sugar beet and the Israelis explained banal stuff as if they had invented the deep plate. We wanted to get out and see the country and then there was fence around the kibbutz and they kept talking about security, so we were scared. Those who chose to go, got to see Israel and received LE 1000 in pocket money, but we did not learn anything."

In other words, the interviewee does not accept a 'banal' production of landscape whereby Egyptian and Israeli deserts are alike. He explains that a) ecological conditions (e.g. soil types) were different in the Egyptian Western Desert from the Dead Sea area where the training courses took place, that b) therefore the crop mix was different, and c) that therefore the advice provided seemed "banal" and "didn't teach them anything." The farmer indirectly questions the arguments for agricultural cooperation, namely that Israel can provide much-

${ }^{15}$ Interviewed 16/10/2003. 
needed desert farming know-how and technology. Thereby the only remaining argument for the training courses is peace-building through image politics, but for this farmer agricultural training courses did not change his sentiments towards Israel:

Me: "Did it change your view of Israel and Israelis?"

Egyptian D: "You can put me in a palace and make me live like a king, but the moment I read the paper and see a Palestinian child killed by the Israelis, how do you think I think about them then? We met people who were very happy to see us, but I felt it was a very superficial kindness. I kept thinking this person hugging me could have killed an Egyptian or a Palestinian. It was not different from what I had expected. They were friendly - it is normal to be friendly towards one's guests."

Considering the strong resentment towards Israel in the Egyptian public, one may ask why graduates agreed to go on training courses in Israel - especially if they felt they did not learn anything. As pointed out by Bushin et al. (2007), it is important to understand the context and identities of young rural lives: understanding who we are is closely linked to where we are, and this is constantly negotiated. Based on this idea, we should look to the spatial arrangements and the social fabric of the new villages in order to understand how the settlers negotiate in everyday life. Hence, the reason why graduates decide to go to Israel can be found in the whole set-up of the desert communities. The Mubarak villages, which have provided participants for the training courses, are quite unique in the sense that they are made up of a fairly homogenous group of people, namely graduates of more or less the same age. In principle, all graduates are offered the same courses: this means that there is no 'mystery' about why some people go to Israel. Moreover, the option is provided through the government, so it is legal. It has to be kept in mind that desert cultivation and settlement is fairly recent and the settlers in the new villages are highly dependent on the government. Technology for desert cultivation and training, for instance, is provided through the government. This means that there is little other alternative for the new settlers than to rely on government advice.

Moreover, as I have shown elsewhere, the spatial arrangements of the new lands allow new social patterns and norms to emerge (Adriansen 2003, 2009). Instead of seeing the new villages as the margin, they can be perceived as the frontier, where one has to be more open and progressive to survive. This is the explanation given for women's increased freedom to 
engage in different activities. And the cooperation with Israelis can be understood in this perspective. While the delta villages are marked by social control and secret police, the spatiality of the new lands allows for more manoeuvring in everyday life.

In general, the interviewees were under the impression that settlers need all the help they can get. The interviewees all subscribed to the discourse that Egyptians themselves did not have the experience and technology for desert cultivation and therefore they had to seek help elsewhere. The government officials and development workers whom I interviewed argued that Israelis are the most experienced with regard to desert agriculture, and therefore that cooperation should take place. After the second Palestinian intifada, however, Egypt, Israel and Denmark agreed that it was problematic to send Egyptian graduates to Israel and Israeli experts to the Egyptian desert. Therefore, the training of graduates is not part of the on-going agricultural cooperation financed by Denmark: efforts now focus on research into dryland agriculture instead (UM 2010).

\section{Concluding remarks}

Egyptian-Israeli peace cooperation is difficult to understand without understanding Egyptian agrarian politics. Bush $(2007,2011 b)$ and Mitchell $(1991,1995,2002)$ have argued that focusing on a looming environmental-demographic crisis enabled the government to distract the focus from the social problems, unequal distribution of land, and dire consequences of structural adjustment programmes. Furthermore, Sowers (2011) shows how an ecologicaldemographic narrative of crisis has been dominant, thereby legitimising spatial expansion into the desert. This paper can be seen along the same lines: with the discourse of agrarian development through techno-politics and the reclamation of desert land, the Egyptian government could justify its cooperation with Israel - an expert with regard to desert development. Thereby agricultural cooperation is part and parcel of neo-liberal agrarian politics in Egypt. Cooperation with Israeli was an element in the deregulation of agriculture. It was a small element in a large programme of agrarian transformation, but it was an important element in the land reclamation programme in general and in the Mubarak Project in particular. Hence, the cooperation with Israel cannot be seen in isolation from the transformation of the agricultural sector that took place almost simultaneously with the 'peace-building' projects. What began as an attempt to normalise and solve the Arab-Israeli 
conflict (at least discursively) ended up triggering and consolidating major agrarian, sociopolitical and economic transformations in Egypt.

This paper has been an attempt to provide empirically-based, geographical knowledge and thereby to fill a gap in the existing regional scholarship. The agricultural cooperation between Egypt and Israel can be seen as an extreme case (in Flyvbjerg's understanding), from which we can learn about the cooperation between two former enemies in a post-conflict situation. The paper has shown that agricultural cooperation between Egypt and Israel is a multi-level phenomenon which is played out locally in the Egyptian desert and integrated into the politics and economics of land reclamation and international development aid. The former minister of agriculture, Wali, played an important role in establishing the cooperation and was very interested in normalising relations. Nevertheless, the agricultural cooperation continued after his downfall. The reason for this is linked to the production and reproduction of landscape through the discourses of agrarian development. Mitchell $(1991,1995)$ has shown how "America's Egypt" should develop through the transfer of technology and know-how from the West. When the agricultural cooperation started to focus on land reclamation and desert agriculture, it thus became legitimate to seek help and cooperate with Israel, because landscape was produced as similar (although it was not) and because the cooperation could be spatially located outside the symbolic Egyptian heartland - the Nile delta and valley. Without a focus on the spatiality of agricultural cooperation, we cannot understand why it was a success. It can be concluded that the conditions for agricultural cooperation were unique. This extreme case entails unique actors (Wali) and mechanisms (productions of landscape and construction of space/place), which cannot be transferred to other areas. Thus, despite its continuation, agricultural cooperation in itself holds little hope for the future of Egyptian-Israeli cooperation and thus the normalisation of relations and continued peace. 


\section{Acknowledgements}

The paper is based on fieldwork in reclaimed lands in Lower Egypt and on interviews with people involved in the "peace projects" between Israel, Egypt, Jordan and the Palestinian Authority. The interviewees were promised confidentiality, so they will not be mentioned by name. However, I am indebted to them for having shared their time and knowledge with me. Fieldwork in Egypt was carried out in collaboration with the Desert Development Center at the American University in Cairo. I wish to thank Dr. Richard Tutwiler, director of DDC, for facilitating my research. The fieldwork would not have been possible without the helpful and friendly support from the employees at DDC, especially Mohsen Nawarra who helped out during difficult situations in the field. Last but not least thanks are due to Nagwa Hassan and Vivian Salama who at different points in time acted as interpreters and assistants and proved invaluable in the 'lush Egyptian desert'. The research was funded through the Danish Social Science Research Council. All the usual disclaimers apply. 


\section{References}

Abdelaty, S. (2003) A new tack. Al-Ahram Weekly

625. http://weekly.ahram.org.eg/2003/625/eg3.htm (accessed 15/03 2013)

Adriansen, H. K. (2003). Egypt's Desert Lands: New Spaces of Opportunity Or New Spaces of Poverty?. DIIS Working Paper, no. 2003:

9. https://www.academia.edu/6680610/Egypts Desert Lands New Spaces of Opportunity or new Spaces of Poverty

Adriansen, H. K. (2007). Rural childhoods in Egypt's desert lands. DIIS Working Paper, no. 2007: 15. http://www.diis.dk/en/research/rural-childhoods-in-egypts-desert-lands

Adriansen, H. K. (2009). Land reclamation in Egypt: a study of life in the new lands. Geoforum, 40 (4), 664-674.

Adriansen, H. K. (2012). Timeline interviews: A tool for conducting life history research.

Qualitative Studies, 3 (1), 40-55.

Adriansen, H. K., and Madsen, L. M. (2004). Constructing multiple ruralities: practices and values of rural dwellers. Geographies of Rural Cultures and Societies. Ashgate, London, pp. 7999.

Arad, R., Hirsch, S., Tovis, A. (1983) The economics of peacemaking: Focus on the EgyptianIsraeli situation. Macmilliam Press, Bath.

Azmeh, S. (2014). Trade regimes and global production networks: The case of the Qualifying Industrial Zones (QIZs) in Egypt and Jordan. Geoforum, 57, 57-66.

Barnes, J. (2012a). Mixing waters: The reuse of agricultural drainage water in Egypt. Geoforum. Online version http://www.sciencedirect.com/science/article/pii/S0016718512002655 (accessed 18/10 2013)

Barnes, J. (2012b). Pumping possibility: Agricultural expansion through desert reclamation in Egypt. Social Studies of Science, 42(4), 517-538.

Barnes, J. (2013) Expanding the Nile's Watershed: The Science and Politics of Land Reclamation in Egypt. In Mikhail, A. (ed.) Water on Sand: Environmental Histories of the Middle East and North Africa, pp.251-271. New York: Oxford University Press 
Bush, R. (2007) Politics, power and poverty: twenty years of agricultural reform and market liberalisation in Egypt. Third World Quarterly 28 (8): 1599-1615.

Bush, R. (2011a) Egypt: a permanent revolution? Review of African Political Economy, 38:128, 303-307

Bush, R. (2011b) Coalitions for Dispossession and Networks of Resistance? Land, Politics and Agrarian Reform in Egypt. British Journal of Middle Eastern Studies 38 (3): 396-397.

Bushin, N., Ansell, N., Adriansen, H. K., Lahteenmaa, J., and Panelli, R. (2007). Reflecting on contexts and identities for young rural lives. Global Perspectives on Rural Childhood and Youth. Routledge, USA, 69-80

Castree, N. (1995). The nature of produced nature: materiality and knowledge construction in Marxism. Antipode, 27 (19), 12-48.

Cohen, S. (2011). Environmentalism Deferred Nationalisms and Israeli/Palestinian Imaginaries. In Davis, D.K. and Burke, E. (eds.) Environmental imaginaries of the Middle East: history, policy, power, and practice, pp. 246-264. Ohio University Press, Athens.

Cresswell, T. (2004). Place: a short introduction. Blackwell, Coventry.

Davis, D. K. and E. Burke (eds.) (2011). Environmental Imaginaries of the Middle East and North Africa. Ohio University Press, Athens.

Dixon, M. (2014). The land grab, finance capital, and food regime restructuring: the case of Egypt. Review of African Political Economy, 41 (140), 232-248.

Drozdz, M. (2012). L'ouest égyptien, une périphérie? 50 ans d'évolutions socio-territoriales. M@ppemonde 104 (4): 1-21.

El-Din, E. (2000). Al-Shaab journalists re-convicted. Al-Ahram Weekly, 6-12 April 2000, Issue No. 476 http://weekly.ahram.org.eg/2000/476/eg7.htm (accessed 16/08 2014)

El-Mahdi, R. (2011). Labour protests in Egypt: causes and meanings. Review of African Political Economy 38 (129): 397-399. 
Enien, R.R., A.A. Sharif, M.A. Monem, A. Kamel, M.B. Solh, M. Bedier and H. Khalifa (2000) A new research paradigm for sustainable agriculture in Egypt. Experimental Agriculture 36 (2): 265-271.

Flyvbjerg, B. (2006). Five misunderstandings about case-study research. Qualitative inquiry, 12(2), 219-245.

Gerges, F. A. (1995). Egyptian-Israeli relations turn sour. Foreign Affairs, 74 (3): 69-78.

Harvey, D. (2009). Cosmopolitanism and the Geographies of Freedom. Columbia University Press.

Ibrahim, F.N. and Ibrahim, B. (2003) Egypt: An economic geography. I.B. Tauris, Bodmin. IMFA, Israeli Ministry of Foreign Affairs (1998) Danida - Trilateral program for agricultural development.http://www.mfa.gov.il/MFA/Mashav+\%E2\%80\%93+International+Development/ Activities/DANIDA+-+Trilateral+Program+for+Agricultural+Devel.htm?DisplayMode=print (accessed 15/03 2013)

JAC, Joint Agricultural Committee (1999). 20 Years of agricultural cooperation Israel-Egypt, 1979-1999. Haifa Session, 8 September 1999. State of Israel, Ministry of Agriculture and Rural Development; The Arab Republic of Egypt, Ministry of Agriculture and Land Reclamation. Kamel, S. and C. Dahl (2005). The economics of hybrid power systems for sustainable desert agriculture on Egypt. Energy 30 (8): 1271-1281.

Keynan, A., and Shoham, D. (1998). Scientific Cooperation in Agriculture and Medical Research as a Means for Normalizing Relations between Egypt and Israel. Annals of the New York Academy of Sciences, 866(1), 182-199.

Kleinberg, K. B., and Fordham, B. O. (2010). Trade and foreign policy attitudes. Journal of Conflict Resolution, 54(5), 687-714.

Kliot, N. (1997). The grand design for peace: planning transborder cooperation in the Red Sea. Political Geography, 16(7), 581-603.

Lavie, S., and Young, W. C. (1984). Bedouin in limbo: Egyptian and Israeli development policies in southern Sinai. Antipode, 16(2), 33-44. 
Malm, A., and Esmailian, S. (2012). Ways in and out of vulnerability to climate change: abandoning the Mubarak Project in the northern Nile Delta, Egypt. Antipode 45 (2): 474-492

MALR, Ministry of Agriculture and Land Reclamation (2000) Mubarak national scheme for settling and developing newly reclaimed lands. Publication from the Egyptian Ministry of Agriculture and Land Reclamation. May 2000.

MEI, Middle East Institute (2009): The Legacy of Camp David. Middle East Institutes Viewpoints, special edition, March

2009. http://www.mei.edu/sites/default/files/publications/Legacy-Camp-David.pdf (accessed 091013)

Meyer, G. (1978) Erschliessung und Entwicklung der Ägyptischen Neulandsgebiete. Erdkunde 32: $212-227$.

Meyer, G. (1994) Land reclamation and development of new agricultural land in Egypt. Applied Geography 44: 59-71.

Meyer, G. (1998) Economic changes in the newly reclaimed lands: from state farms to small holdings and private agricultural enterprises. In Hopkins, N.S. and K. Westergaard (eds.) Directions of change in rural Egypt, pp. 334-356. The American University in Cairo Press, Egypt.

Mitchell, T. (2002) The rule of experts: Egypt, techno-politics, modernity. University of California Press, USA.

Mitchell, T. (1995) The object of development: America's Egypt. In J. Crush (ed.) Power of development, pp. 129-157. Routledge, Padstow.

Mitchell, T. (1991). America's Egypt: discourse of the development industry. Middle East Report, 169, 18-36.

Nielsen, T.T. and H.K. Adriansen (2005) Government policies and land degradation in the Middle East. Land Degradation \& Development 16 (2): 151-161

Quandt, W.B. (1988) Introduction. In Quandt, W.B. (ed.) The Middle East: Ten years after Camp David pp. 1-18. The Brookings Institution, Virginia.

Quandt, W. B. (2010). Peace process: American diplomacy and the Arab-Israeli conflict since 1967. Brookings Institution Press \& University of California Press, Virginia. 
Reuveny, R., and Kang, H. (1998). Bilateral trade and political conflict/cooperation: Do goods matter? Journal of Peace Research, 35(5), 581-602.

Said, A.M. (2012) The Egyptian-Israeli peace treaty: To change or not to change? Al-Ahram online 10/10 2012. http://english.ahram.org.eg/NewsContent/4/0/55214/Opinion/TheEgyptianlsraeli-peace-treaty-To-change-or-not-.aspx (accessed 15/03 2013)

Sharp, J.M. (2011). Egypt in Transition. Congressional Research Service CRS Report for Congress, May 4, 2011. http://www.refworld.org/docid/4e5c81712.html (accessed 16/06 2014)

Sharp, J.M. (2013). Egypt: Background and U.S. Relations. Congressional Research Service CRS Report for Congress, June 27, 2013. http://www.fas.org/sgp/crs/mideast/RL33003.pdf (accessed 05/11 2013)

Smith, N. (1984). Uneven Development: Nature, Capital and the Production of Space. Oxford: Basil Blackwell.

Sowers, J. (2011). Re-mapping the nation, critiquing the state: narrating land reclamation for Egypt's New Valley. In Davis, D.K. and Burke, E. (eds.) Environmental imaginaries of the Middle East: history, policy, power, and practice, pp. 158-191. Ohio University Press, Athens.

Springborg, R. (1979) Patrimonialism and policy making in Egypt: Nasser and Sadat and the tenure policy for reclaimed lands. Middle Eastern Studies 15, 1: 49-69.

Tuan, Y. E. (1977). Space and place. Arnold, London.

UM, Udenrigsministeriet (Danish Ministry of Foreign Affairs) (2010). Regionalt landbrugsprogram i Mellemøsten (Regional agricultural programme in the Middle East). http://um.dk/da/ /media/UM/Danish-site/Documents/Danida/OmDanida/Styrelse/Bes/2010/nov/12RegionaltlandbrugsprogramiMellemsten.ashx (accessed 16/08 2014)

Van Ham, P. (2001). The rise of the brand state: the postmodern politics of image and reputation. Foreign Affairs, 2-6.

Wolff, P. (1993) Land reclamation in Egypt. Tropenlandwirt 94: 103-117.

Yetiv, S. A. (1997). Peace, interdependence, and the Middle East. Political Science Quarterly, 112(1), 29-49. 

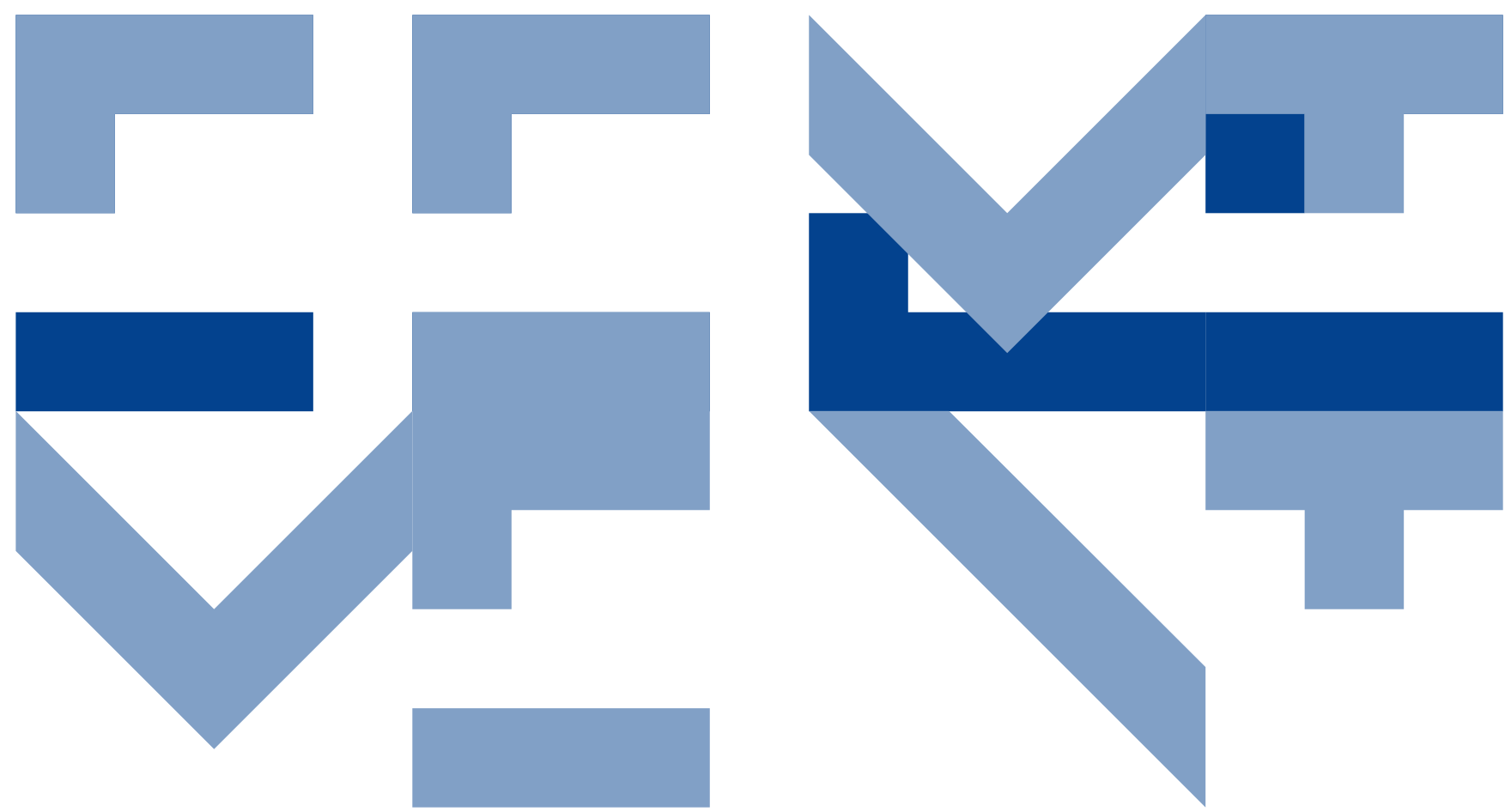

An important aspect of the 1979 Peace Treaty between Egypt and Israel was normalisation through cooperation. However, this has proven difficult; especially the 'Arab street' has been against the collaborative activities. After the Arab Spring, it has been questioned whether the Peace Treaty would be upheld. In order to understand the future of the Egyptian-Israeli peace, this paper uses a geographical approach to examine why agrarian cooperation between the two countries has succeeded when other areas of cooperation struggle. The paper draws on different fields of research - agrarian politics in Egypt, notably land reclamation, and the political economy of The Peace Treaty. These are combined through a geographical gaze focussing on the production of landscape and the construction of space/place. Agricultural cooperation took off when it began to concern desert agriculture. For Egypt, cooperation within this field could be justified through existing discourses of agrarian development by transfer of technology and know-how. For Israel, training courses in particular served as a means to normalisation through image politics. It is concluded that the (spatial) conditions for agricultural cooperation were unique. Thus, despite its continuation, agricultural cooperation in itself holds little hope for the future of the Egyptian-Israeli peace politics of cooperation. 